\title{
One World, One Dream
}

あけましておめでとうございます，今年はいよいよ北京五輪が開かれます，表題は実はその 北京オリンピックのスローガンです，元の中国語は「同一個世界，同一個夢想」で，その日本 語訳は「一つの世界, 一つの夢」です，北京オリンピック組織委員会の説明によると，スロー ガンは,「緑色奥運（グリーン・オリンピック）」「高科技奥運（ハイテク・オリンピック）」「人 文奥運（ピープルズ・オリンピック）」という三大理念を反映しているそうです.

その「高科技奥運」は, 別名「数字奥運」(デジタル・オリンピック) と呼ばれ, 目玉の一つは 私たち自然言語処理研究者も関心を持つ「多言語知能情報サービス」です．目指すのは「いつで も」,「どこでも」，「だれでも」ほしい情報を言葉の障壁なく簡単に取得できる，いわば，「ユビ キタス十言語バリアフリー」的な情報環境の実現です。そのために，中国科学院をはじめ，多 数の研究機関及び企業が一丸になり, 多言語機械翻訳, 多言語音声認識, 多言語音声合成, 多 言語コンテンツ管理と情報検索, 知的ヒューマンインターフェースなどの研究開発に余念なく 取り組んでいるようです。

このような試みはどこまで成功できるかは分かりません，しかし，中国の当該分野の研究水 準が急速に向上してきているのも間違いない事実で，個人的には多言語情報処理，とりわけ日 中の言語処理について, より多くの日本人研究者が関心を持ち, 積極的に関わっていくことが 時代の流れではないかと考えます。そこで, 皆様の日中交流の契機にでもなればと考え, 巻頭 言としてあまり相応しくないことを認識しつつ，中国の自然言語処理事情について日本のそれ と比較しながら紹介したいと思います。

中国では言語処理の学術団体としてわが言語処理学会と同等（もしくは同等以上）の役割を 果たしているのは「中文信息学会」(中国語情報処理学会) です。この学会は中国科学技術協会 の第一級の学術団体として 1981 年に創立され，今は約 2000 名の会員を抱えています. 扱う分 野は学会名のとおり，メインはテキストベースの言語処理ですが，それに限らず，音声処理は もちろんのこと, 中国語と関係があれば画像処理技術までも守備範囲に入ります。このように, 伝統・規模・扱う分野の広さはいずれもわが言語処理学会の先を行っているように思います。学 会のオフイシャルジャーナルとして「中文信息学報」があり，それも 1986 年と，やはり非常に 早い時期に創刊されました。この雑誌は 2 か月ごとに定期的に刊行され，今手元にある最新の もの（21 巻 5 号, 2007 年 9 月発行）は A4 版で査読つき論文 24 篇が収録されています。学術論 文のほか, 国際・国内の関連会議の紹介記事（今回はACL2007 の参加感想など）や会議の知ら せなどが揭載されています．学会主催の国内外の会議も多数ありますが，わが言語処理学会の 年次大会に相当するのは「全国計算言語学連合学術会議」です。この会議は 1991 年から始めら れ，2 年ごとに定期的に開催されています. 日本の年次大会との違いは主に以下の三点が挙げ られます。一つは, 論文はすべて査読ありで, たとえば筆者が最近参加した 2005 年の会議にお 
いては，投稿された 185 篇の論文に対し，82 篇が regular 論文，39 篇がポスター発表として採 録されていました。また, 開催校はたいへん名誉なことのようで, 開催希望校（特に地方の大 学) が多く, その選定過程がそう容易ではないようです.さうに, 言語学関係の論文が発表論 文のかなりの割合を占めていることです（たとえば上記 82 篇の regular 論文のうち, 文法分析 などが 24 篇も占めています). ところで, 言語処理に限る話ではないのですが, 中国人研究者 は中国国内にとどまらず海外に行っていろいろな国で研究を行っています. 主要な国際会議を 利用して中国語処理の研究者が集まり学術交流ができればという考えの下で SIGHAN という中 国語処理に特に焦点を当てた Special Interest Group が ACL の下に設立されています. 台湾で 開かれた COLING2002 で第一回の併設ワークショップが開催されて以来, ワークショップは毎 年開催され，今年インドで開かれたIJCNLP2008で 6 回目を数えます．特筆すべきは札幌開催 の ACL2003 のワークショップにおいて初めて中国語単語分割のコンテスト (SIGHAN Bakeoff) が行われ，今回で 4 回目となりました。また, コンテストの課題も単語分割タスクから, 品詞 推定と固有表現抽出夕スクまで拡張されています.

このように, 中国の自然言語処理の研究は多方面にわたって活発に展開されていることが分 かります。また, 少し注意を払うと, 最近の各主要国際会議に中国語関連の論文が大分增えて いることにも気づきます。したがって，中国の自然言語処理の研究水準の急速な向上と研究環 境の大幅な改善により, 日中両国の研究者にとって, 今以上に効果的な研究交流・研究協力が 可能になったのです．また，自然言語処理に扔いては，「機械翻訳」や「言語横断情報検索」な ど, 2 言語または多言語が関係することが多いので, 他分野よりも国際的な研究交流・研究協 力が必要となります。実際，これまでも日中の間にさまざまな研究交流や研究協力が進められ てきました、たとえば筆者も初回から携わってきた，両国の自然言語処理研究の第一線で活躍 している研究者たちによる「日中自然言語処理共同研究促進会議」を 2001 年にスタートして以 来，毎年日中の両国で交互に開いており，今は日中自然言語処理研究者の交流の場としてすっ かり定着したように思います。このような研究交流の積み重齐は今後, 必ず量から質へと変化 して大きな成果に結びっくことでしょう.

表題とは大分かけ離れた，とりとめのない「中国紹介」の話になってしまいましたが，皆様 に少しでも中国の自然言語処理の事情を分かっていただければたいへん幸いに思います。そし て，表題の話に戻せば，私たち自然言語処理研究者は正に，言葉の壁を乗り越えたい「一つの 夢」を抱きながら，言語バリアフリーな素晴らしい「一つの世界」の実現に向けて日々走り続 けているのです。そう思いつつ，筆をおきます。

馬 青（龍谷大学理工学部） 